\title{
Early Diagenesis of Plitvice Lakes Waterfall and Barrier Treavertine Deposits
}

\section{Les débuts de la diagénèse de la chute des lacs Plitvice et des dépôts de la barrière de travertin Frühe Diagenese des Wasserfalls der Plitvice-Seen und Travertin-Barriere-Ablagerungen.}

\author{
Henry S. Chafetz, Dusan Srdoc et Nada Horvatincic
}

Volume 48, numéro 3, 1994

Les travertins

Travertines

URI : https://id.erudit.org/iderudit/033006ar

DOI : https://doi.org/10.7202/033006ar

\section{Aller au sommaire du numéro}

\section{Éditeur(s)}

Les Presses de l'Université de Montréal

\section{ISSN}

0705-7199 (imprimé)

1492-143X (numérique)

\section{Découvrir la revue}

Citer cet article

Chafetz, H. S., Srdoc, D. \& Horvatincic, N. (1994). Early Diagenesis of Plitvice Lakes Waterfall and Barrier Treavertine Deposits. Géographie physique et Quaternaire, 48(3), 247-255. https://doi.org/10.7202/033006ar

\section{Résumé de l'article}

Le travertin est à l'origine de la formation de chutes spectaculaires, de barrières et de dépôts lacustres subaquatiques à grains fins partout dans le parc national Plitvice, en Croatie. Les barrières de travertin forment des barrages derrière lesquels est situé le complexe des lacs Plitvice. La chute et les barrières de travertin comprennent trois générations de sparites de calcite à basse teneur de magnésium. Les précipitations initiales sont généralement composées de sparite à cristaux impurs très fins à moyens allant de la forme isométrique à celle de la lame. Une génération subséquente est constituée de couches transparentes isopaques de cristaux plus ou moins fins en forme de lame. De plus, les croûtes laminées de l'ordre du centimètre, constituées de sparite en lame ou colonnaire, représentent le type de précipitations habituellement observées autour des accumulations de micrite à l'intérieur des plus anciens travertins. Par contre, les dépôts de remblaiement lacustre comprennent surtout des rhomboèdres de calcite de 3 à 8 p.m. Les analyses pétrographiques montrent clairement que les cyanobactéries, les champignons ou autres organismes microbiens creusent la sparite et la micritise. Cette micritisation de la sparite est répandue partout dans la chute et les dépôts de barrière. Les cristaux de sparite en lame comprennent ceux qui sont anciens et ceux dont la morphologie originelle en lame ne peut être interprétée qu'à l'aide des cristaux latéraux adjacents. Certains échantillons montrent de nombreuses générations de sparites qui ont subi une micritisation plus ou moins intense. La micritisation de la sparite résulte en une accumulation complètement micritisée où la composition originelle de la sparite a été oblitérée.
Tous droits réservés @ C Les Presses de l'Université de Montréal, 1994

Ce document est protégé par la loi sur le droit d'auteur. L'utilisation des services d'Érudit (y compris la reproduction) est assujettie à sa politique d'utilisation que vous pouvez consulter en ligne.

https://apropos.erudit.org/fr/usagers/politique-dutilisation/ 


\section{EARLY DIAGENESIS OF PLITVICE LAKES WATERFALL AND BARRIER TRAVERTINE DEPOSITS}

Henry S. CHAFETZ, Dusan SRDOC* and Nada HORVATINCIC; first author: Department of Geosciences, University of Houston, Houston, Texas, U.S.A. 77204-5503; second and third authors: Ruder Boskovic Institute, P.O. Box 1016, 41001 Zagreb, Croatia.

\begin{abstract}
Travertine forms spectacular waterfalls, barriers, and subaqueous finegrained lake-fill accumulations throughout the Plitvice National Park, Croatia, northwestern Yugoslavia. Barrier deposits form dams, behind which, the lakes of the Plitvice complex are situated. Three generations of low-magnesian calcite spar comprise the waterfall and barrier forming travertines. The initial precipitates generally are composed of cloudy, very finely to medium crystalline equant to bladed spar. A later generation is composed of clear, isopachous layers of medium to coarsely crystalline bladed crystals. Additionally, centimeter-thick laminated speleothem-like crusts, composed of clear, bladed to columnar spar, are the common precipitates around micritic accumulations within the older travertine. In comparison, the lake-fill deposits are primarily composed of moderately (recent lake-fill deposits) to welldeveloped (relict lake-fill deposits) 3-8 $\mu \mathrm{m}$ calcite rhombohedrons. Petrographic analyses clearly show that cyanobacteria, fungi, and/or other microbial organisms bore into the spar and micritize it. This sparmicritization is pervasive throughout the waterfall and barrier deposits. Bladed spar crystals range from those which are pristine to those whose original bladed morphology can only be interpreted by comparison with laterally adjacent crystals. Individual samples display multiple generations of spar which have undergone various degrees of sparmicritization. Sparmicritization results in a thoroughly micritized accumulation in which evidence of the original spar composition has been completely obliterated.
\end{abstract}

RÉSUMÉ Les débuts de la diagénèse de la chute des lacs Plitvice et des dépôts de la barrière de travertin. Le travertin est à l'origine de la formation de chutes spectaculaires, de barrières et de dépôts lacustres subaquatiques à grains fins partout dans le parc national Plitvice, en Croatie. Les barrières de travertin forment des barrages derrière lesquels est situé le complexe des lacs Plitvice. La chute et les barrières de travertin comprennent trois générations de sparites de calcite à basse teneur de magnésium. Les précipitations initiales sont généralement composées de sparite à cristaux impurs très fins à moyens allant de la forme isométrique à celle de la lame. Une génération subséquente est constituée de couches transparentes isopaques de cristaux plus ou moins fins en forme de lame. De plus, les croûtes laminées de l'ordre du centimètre, constituées de sparite en lame ou colonnaire, représentent le type de précipitations habituellement observées autour des accumulations de micrite à l'intérieur des plus anciens travertins. Par contre, les dépôts de remblaiement lacustre comprennent surtout des rhomboèdres de calcite de 3 à $8 \mu \mathrm{m}$. Les analyses pétrographiques montrent clairement que les cyanobactéries, les champignons ou autres organismes microbiens creusent la sparite et la micritise. Cette micritisation de la sparite est répandue partout dans la chute et les dépôts de barrière. Les cristaux de sparite en lame comprennent ceux qui sont anciens et ceux dont la morphologie originelle en lame ne peut être interprétée qu'à l'aide des cristaux latéraux adjacents. Certains échantillons montrent de nombreuses générations de sparites qui ont subi une micritisation plus ou moins intense. La micritisation de la sparite résulte en une accumulation complètement micritisée où la composition originelle de la sparite a été oblitérée.
ZUSAMMENFASSUNG Frühe Diagenese des Wasserfalls der Plitvice-Seen und Travertin-Barriere-Ablagerungen. Kalktuff bildet prächtige Wasserfälle, Barrieren und feinkörnige Unterwasser-Seeablagerungen quer durch den gesamten Nationalpark von Plitvice, Kroatien, nordwestliches Jugoslawien. Die Travertin-Barrieren bilden Dämme, hinter denen sich die Gesamtheit der Seen von Plitvice befindet. Der Wasserfall und die Travertin-Barrieren umfassen drei Generationen von Kalkspat mit niedrigem Magnesiumgehalt. Die anfänglichen Ausscheidungen bestanden im allgemeinen aus Spat mit trüben, sehr feinen bis mittleren Kristallen von isometrischer Form bis Plättchen-Form. Eine spätere Generation besteht aus klaren, isopachen Schichten von mittleren bis grob kristallinischen PlättchenKristallen. Außerdem sind zentimeterdicke blättrige Krusten, bestehend aus reinem blatt- bis saulenförmigem Spat die üblichen Ausscheidungen um die mikritische Akkumulationen innerhalb der älteren Travertine. Hingegen bestehen die Seeauffüllungs-Ablagerungen vor allem aus mäßig (neuere Seeauffüllungs-Ablagerungen) bis gut entwickelten (frühere Seeauffüllungs-Ablagerungen) Kalkspat-Rhomboedern von 3-8 $\mu \mathrm{m}$. Die Gesteinsanalysen zeigen deutlich, daß die Zyanbakterien, Pilze und andere Mikroorganismen den Spat aushöhlen und inn mikritisieren. Diese SpatMikritisierung durchdringt den Wasserfall und die Barriereablagerungen. Die Spatplättchenkristalle reichen von den ursprünglichen bis zu denen, deren ursprüngliche Plättchenmorphologie nur durch Vergleich mit lateral angrenzenden Kristallen interpretiert werden kann. Einzelne Proben zeigen zahlreiche Generationen von Spat, die verschiedene Grade der Spat-Mikritisierung durchlaufen haben. Spat-Mikritisierung führt zu einer Mikritisierungs-Anhäufung, in welcher die ursprüngliche Spatzusammensetzung getilgt worden ist. 


\section{INTRODUCTION}

Travertine is presently forming throughout the Plitvice Lakes region, along the Matica River - Plitvice Lakes Korana River system, Plitvice National Park, Croatia, in former northwestern Yugoslavia (Fig. 1). The travertine occurs as deposits associated with spectacular waterfalls, luxuriant barrier accumulations (barrage travertine), and subaqueous fine-grained lake-fill deposits. The most spectacular, highest waterfalls occur where spring-fed side streams in hanging valleys enter the main river valley. Other falls occur where travertine barriers form dams, behind which the various lakes are situated. The active barriers exist at the downstream ends of the numerous lakes. The water flows over and percolates through barriers in a myriad of rivulets. This keeps the travertine wet and maintains the abundant flora. The initial travertine accumulations are extremely porous on a micro- and macro-scale and, with time, the porosity is occluded and the sediment lithified. The nature of the initial precipitates comprising the waterfall and barrier accumulations and their early diagenesis during lithification are the primary concerns of this investigation.

\section{METHODS}

A representative suite of samples were collected from a wide variety of active and non-active (older travertine) deposits from throughout the Plitvice Lakes system. Samples were examined using binocular, petrographic (standard, fluorescent, white card, and cathodoluminescent), and scanning electron microscopes. Fluorescent (Dravis and Yurewicz, 1985 ) and white card (Folk, 1987) microscopy are valuable techniques to enhance the presence of organic matter in thin sections. X-ray diffraction analysis was used to determine the carbonate mineralogy.

\section{WATERFALL AND BARRIER TRAVERTINES}

Waterfall and barrier travertine accumulations (Chafetz and Folk, 1984) are very similar. They both form at a break in the slope of running water, are built primarily by carbonate encrustation around plants, and have a similar highly irregular stratification or paucity of stratification. These types of deposits generally have a wedge-shaped overall geometry (Emig, 1917; Marker, 1971; Ordonez and Garcia del Cura, 1983; Pedley, 1987; Love and Chafetz, 1990) with the thickest accumulations at the present or past sites of the falls and/or barriers. The accumulations rapidly thin in both the upstream and downstream directions. Deposits comprising the streambed, upstream as well as downstream from the waterfall sites, generally are composed of essentially flat-lying semi-lithified travertine. In contrast, the travertines at the sites of the waterfalls commonly have steeply dipping to vertically oriented "strata". The steeply dipping deposits are predominantly the result of carbonate encrustation around plants, i.e., predominantly algae and mosses, which hang down the vertical face of the falls. The barrier travertines, analogous to the barrage tufa described by Pedley (1987), differ from waterfall travertines in that streambed accumulations are not immediately adjacent to the barriers. The barriers dam the water and, as a result, lakes occur immediately upstream and, in some places, downstream of the barriers. Consequently, the barriers are laterally adjacent to lake-fill deposits whereas the waterfalls are laterally adjacent to streambed travertines. The barriers also differ from the waterfall travertines in that the barrier accumulations tend to be composed of a more highly

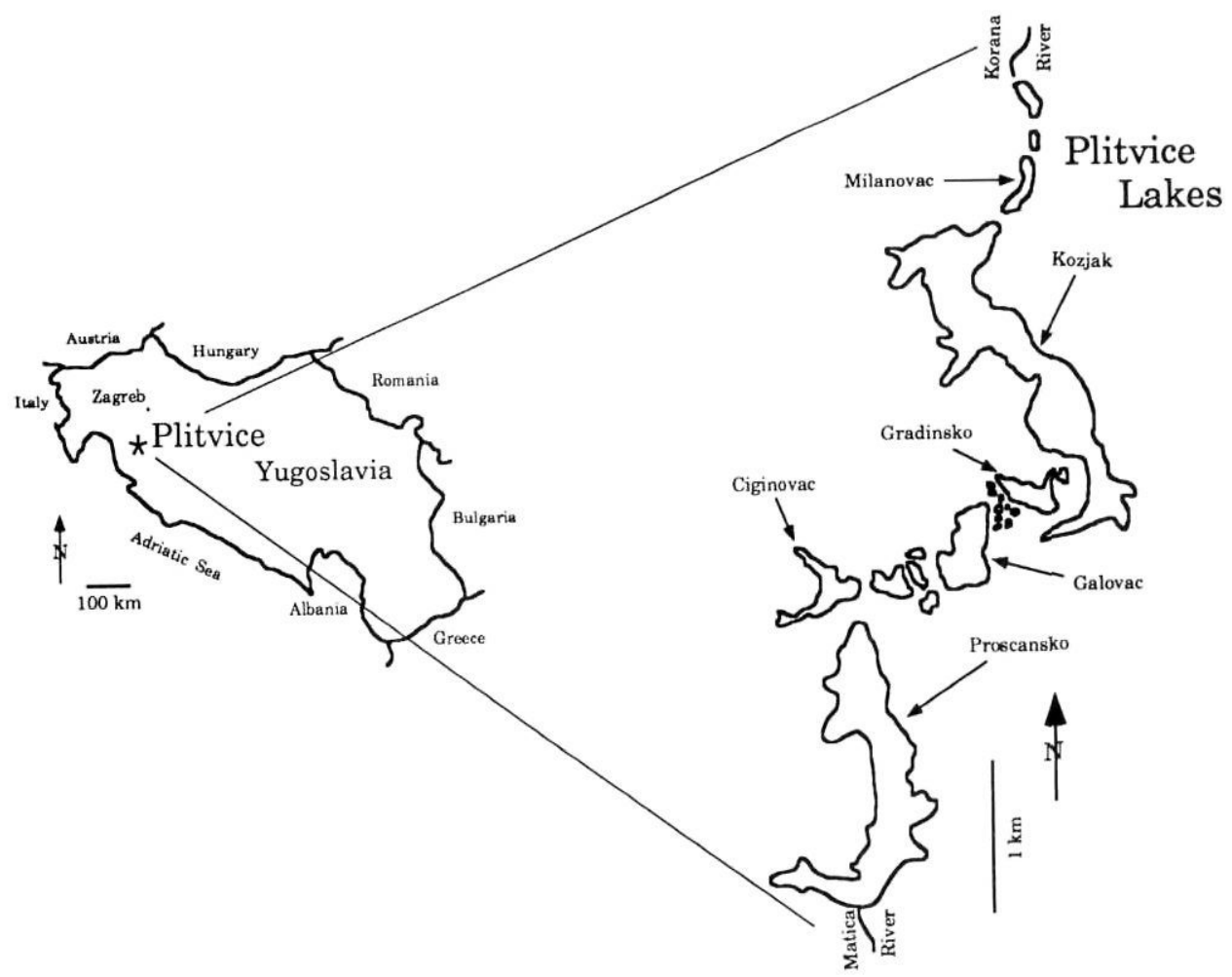

FIGURE 1. Map showing the location of Plitvice within the former country of Yugoslavia as well as expanded view of the Plitvice Lakes area; drainage is to the north. Shown on the expanded view are many of the lakes which comprise the system; the lakes are separated by constructional barriers of travertine (barrage travertine). Numerous spring-fed side streams feed into the Matica River - Plitvice Lakes - Korana River system.

Carte montrant la localisation de Plitvice, dans l'ancienne Yugoslavie, et la région des lacs Plitvice; le drainage se fait vers le nord. Plusieurs des lacs qui font partie du réseau y apparaissent. Les lacs sont séparés par des barrages de travertin. De nombreux ruisseaux latéraux issus de sources se jettent dans le réseau formé par la rivière Matica, les lacs Plitvice et la rivière Korana. 
irregular tangle of plants. Nevertheless, in gross structure, composition, internal framework, etc., the waterfall and barrier travertine accumulations are very similar.

The role of the plants in the precipitation of the travertine, i.e., active inducers of precipitation versus passively coated surfaces, has been a subject of considerable discussion (e.g., Emig, 1917; Golubic, 1973; Marker, 1973; Pentecost, 1978; Chafetz and Folk, 1984; Weijermars et al., 1986; Pentecost and Riding, 1986; Pedley, 1987). Kempe and Emeis (1985) and Emeis et al. (1987), after investigating the lake-fill deposits comprising the Plitvice Lakes travertines, concluded that the biota play a central role in the precipitation of calcium carbonate. The biota (1) remove $\mathrm{CO}_{2}$, which increases the level of saturation of the water, (2) act as a convenient substrate for precipitation, and (3) trap and bind calcite seed crystals within their extracellular polymeric secretions. However, it must be emphasized that the biota will not be able to induce carbonate precipitation unless the waters are saturated to supersaturated with respect to calcium carbonate. The waters at the springs which feed the Plitvice Lakes system range from slightly undersaturated to slightly supersaturated with respect to calcite (Srdoc et al., 1985, tables 1-3). The saturation of the waters increases due to degassing of $\mathrm{CO}_{2}$ in the downflow direction, such that "the majority of streams and lakes where intensive precipitation of calcite takes place have $I_{\text {sat }}$ between 5 and 7" (Srdoc et al., 1985, p. 104). It takes a combination of saturated to supersaturated waters interacting with the biota to result in the precipitation of the travertine. As reported by Kempe and Emeis (1985), a key experiment carried out by Srdoc and staff of the Ruder Boskovic Institute substantiates the significant relationship of the biota to carbonate precipitation within these lakes. They observed that plastic and stainless steel sponges placed within the waters of the Plitvice Lakes were encrusted with plants and carbonate precipitates within a few weeks whereas copper sponges remained barren of plants and no evidence could be found of carbonate precipitation. Copper has a general toxicity to algae (Huntsman and Sundra, 1980) and, therefore, the lack of carbonate precipitate on the copper sponges is attributed to the lack of algae. Consequently, we concur with the findings of Kempe and Emeis (1985) and Emeis et al. (1987), that most of the carbonates comprising the Plitvice Lakes travertines (i.e., the lake-fill deposits) are biologically induced precipitates. Nevertheless, the precipitation of abiotic sparry calcite cement is a common component of the waterfall and barrier travertines. Abiotic precipitation is probably most prevalent in the splash zone of the waterfalls and barriers and produces generation after generation of cements which precipitate on top of the initial biologically induced precipitates of calcite.

\section{PLITVICE WATERFALL AND BARRIER TRAVERTINES}

The Plitvice Lakes waterfalls range in overall dimensions from spectacular falls $70 \mathrm{~m}$ in height (Plitvice Falls) to relatively gently sloping cascades less than a meter high. The high waterfalls occur where side streams enter the main valley. The Plitvice Lakes system is approximately $7 \mathrm{~km}$ in length and the elevation of the water surface drops about $150 \mathrm{~m}$ from the south to the north end (Stoffers, 1975). The barrier travertines comprising the Plitvice Lakes system, while not as high as the waterfalls, reach $500 \mathrm{~m}$ in length as they cross the valley and may be as much as $50 \mathrm{~m}$ thick (Brnek-Kostic, 1989). The actively growing barriers are situated at the downstream end of each lake. The barriers that grow most rapidly, and consequently, are the largest are those farthest downstream (Golubic, 1969; Pedley, 1987), especially at sites where the valley is narrow (Brnek-Kostic, 1989). Accumulation of the calcite occurs very rapidly in the geological sense. The barriers are presently vertically accreting at approximately $1-3 \mathrm{~cm} /$ year, this is indicated by the relative rise in lake levels behind these dams (Kempe and Emeis, 1985; Brnek-Kostic, 1989). The rapid vertical growth of a barrier results in a rise in the water level behind the barrier and, consequently, the barriers upstream are inundated (Golubic, 1969; Brnek-Kostic, 1989). The end result of this process is that a string of individual lakes behind a string of barriers, in time, evolves into one large lake behind one very large barrier.

Vegetation is very luxuriant within the Plitvice Lakes region and plants grow on all exposed and many subaqueous surfaces. The plants, therefore, provide a myriad of surfaces for the precipitation of calcium carbonate. Consequently, the initial travertine deposit does not display any well-developed bedding characteristics and the resultant lithology is extremely variable in both the vertical and horizontal directions. The initial deposits are extremely porous, pores range from millimeter size to cavernous openings meters in diameter. In addition, the subsequent decay of the plant material results in an extensive system of biomoldic secondary porosity, this is most notable with regard to the larger plant remains, such as rootlets, and results in the standard tufa deposit (Julia, 1983; Ford, 1989).

\section{PETROLOGY}

All of the calcite analyzed in the course of this investigation, as well as during the investigations of Kempe and Emeis (1985) and Emeis et al. (1987), is composed of lowmagnesian calcite; Stoffers (1975), however, reported some calcite with as high as 5 mole percent $\mathrm{MgCO}_{3}$. No other nonskeletal mineral precipitate was encountered, i.e., excluding shell material, such as siliceous diatom frustules, only calcite was noted. The calcite displays a wide range in texture, from dense micrites to highly porous tufas to laminated flowstone crusts of spar. The calcite comprising the barrier and waterfall travertines investigated can be divided into: (1) the initial spar coatings on the biologic substrates, (2) isopachous (equal thickness) layers of bladed spar cement, and (3) thick flowstone (speleothem-like) crusts of bladed to columnar spar. These three types of spar, in general, precipitate in the order listed. The coatings on the biologic substrates always occur first and provide the framework for later deposition. Whereas, the flowstone crusts have only been observed in areas now experiencing speleologic processes, i.e., primarily as part of the older travertine accumulations. However, it is not uncommon to find reversals and/or sequence repetition in the resulting spar stratigraphy, e.g., isopachous layers of spar (type 2) may be succeeded by layers of biologically induced precipitates (type 1). This is, in part, a result of shifts in the areas 
of waterfall and barrier growth in response to changes in water flow patterns as the Plitvice Lakes complex evolves.

\section{VARIETIES OF SPAR}

The most common initial travertine accumulation in the Plitvice Lakes area forms as surficial coatings of very finely to medium (4 to $250 \mu \mathrm{m}$ ) crystalline equant calcite spar (type 1). The spar precipitates on any substrate available to the flowing waters, such as cyanobacteria, algae, mosses, leaves of higher taxa of plants, roots, etc. Essentially all of the initial precipitates forming the barrier and waterfall travertines are precipitated on biologic substrates. Consequently, the spar, which coats both living and dead plant material, results in a highly irregular tangle of organic matter coated by calcite. This initial spar is generally cloudy due to the presence of both organic matter and micrite within the crystals. These finely crystalline carbonate deposits not only precipitate on, but are essentially covered by, a microbial flora as the carbonate precipitates. It is our contention that essentially all of this first phase of waterfall and barrier travertine precipitation is probably the result of biologically induced precipitation of calcite. As an example of the intimate relationship between plants and the precipitation of calcite, a favored site of precipitation is around stalks of diatoms which results in equant calcite crystals which have a hole in their center (Fig. 2a). This example of biologically induced precipitation has been noted during the course of other studies concerned with travertine (Love, 1985; Winsborough and Golubic, 1987; Emeis et al., 1987; Love and Chafetz, 1990; Chafetz et al., 1991). Additionally, isopachous layers of bladed spar grow encompassing upright relict fan-shaped cyanophyte bushes (Fig. 2b), similar to those described by Love and Chafetz (1988). The macro-plant material encrusted by calcite undergoes decay fairly rapidly in this environment and produces an extensive network of biomoldic porosity. This biomoldic porosity, along with the initial depositional porosity, is occluded by successive generations of spar.

Later generations of spar (type 2) are generally much coarser than the initial precipitates which formed on the myriad of biologic surfaces. This sparry calcite cement essentially always forms on and within previously formed, highly porous travertine; it lines most exterior surfaces as well as pore spaces (Fig. 2c). The deposits are most commonly composed of isopachous layers of medium to coarsely crystalline bladed crystals, the individual crystals are oriented perpendicularly to the substrate upon which they have grown. The highly irregular surfaces on which this spar grows sometimes results in a layer of spar which has an enterolithic morphology (Fig. 2d). This spar is deposited essentially as clear, inclusion-free crystals which because of the paucity of organic matter within them are not fluorescent (Fig. 2e-h). This petrographically clear, non-fluorescent spar is an abiotic precipitate.

The third type of spar is commonly very coarsely to extremely coarsely crystalline (Fig. 3a), with some bladed to columnar crystals more than $4 \mathrm{~mm}$ long. This spar forms crusts composed of centimeter-thick laminated speleothemlike deposits very similar to the flowstone which commonly forms on the walls of caves, coating stalactites, etc. (Kendall and Broughton, 1978). These crystals are generally clearer than the equant very finely to medium crystalline spar that initially formed on the biologic surfaces (type 1), i.e., the later generations of spar contain fewer inclusions and are free of micritic patches when first formed. Individual bladed to columnar crystals of spar commonly cross growth laminations and contain gas and/or liquid-filled thorn-shaped inclusion, common features in non-marine flowstones (Kendall and Broughton, 1978; Braithwaite, 1979; Chafetz et al., 1985). In addition, some of the flowstone is composed of trigonal prisms with outwardly convex faces (Fig. 3b). Prismatic spar crystals with a trigonal cross section have only been recognized in non-marine carbonates (Chafetz et al., 1985; Jones and McDonald, 1989), with one exception. Internal truncation surfaces attest to alternating periods of erosion and precipitation of older spar crusts. Although there is a close overall resemblance between these crusts and the diagenetically altered algally laminated crusts described by Love and Chafetz (1988), these speleothem-like crusts from the Plitvice Lakes area are abiotic in origin.

\section{SPAR DIAGENESIS}

The petrographic descriptions of the Plitvice Lakes waterfall and barrier travertines indicate that essentially all of the carbonate was precipitated as spar. However, much of the rock is now composed of micrite. Consequently, the origin of the micrite, which is quite abundant, was a major concern. Undoubtedly, some of the micrite was transported from the lake-fill deposits, which are composed of moderately to welldeveloped rhombohedrons of calcite (Fig. 3c), and included within the waterfall and barrier deposits. Other micrite was probably generated within the waterfall and barrier deposits by mechanical abrasion of spar. Nevertheless, that does not account for the rocks that are composed only of micrite (Fig. 3d). These rocks owe their present lithologic make-up to diagenetic alteration that has resulted in the spar being replaced by micrite.

Petrographic analyses provide abundant evidence that spar has been micritized, a process termed sparmicritization by Kahle (1977); the reader is referred to Kahle (1977) for a detailed discussion of the various methods by which this micritization of the spar can occur. Bladed crystais of spar within isopachous layers grade laterally from relatively clean, clear crystals to partially to thoroughly micritized relict crystals (Fig. 3e-g), thus displaying a wide range in degree of sparmicritization within a single layer. Some of the thoroughly micritized material is composed of isolated irregular patches of spar within the micritic rock and close inspection reveals that spar crystal outlines are still present even within the adjacent thoroughly micritized portions of the rock. The outlines are of relict very finely to finely crystalline rhombohedral spar and these crystals are now composed of micrite (Fig. $3 \mathrm{~h}$ ). These relict crystal outlines can only be present if this material was formerly composed of rhombohedrons of spar which have been degradationally altered to micrite.

Fluorescent (Dravis and Yurewicz, 1985) and white card (Folk, 1987) petrographic analyses clearly show that cyanobacteria, fungi, and/or other microbial organisms have bored into the spar (Fig. 4). Boring by these microbial organisms resulted in sparmicritization. Spar can be observed in all 
FIGURE 2. (A) Scanning electron micrograph of finely to medium crystalline rhombohedrons of calcite with numerous holes within them. The holes are the former loci of the stalks of diatoms, the vegetable matter has been removed by baking the sample in a vacuum oven. (B) Photomicrograph of bladed spar crystals with relict fan-shaped cyanophyte bushes (black arrows). Micritic areas (white arrow) are former bladed spar crystals that have been micritized. (C) Photomicrograph showing isopachous (equal thickness) rims of bladed spar (arrows) which lines present and former pore spaces. Note that at a few sites, the clear spar has been micritized. (D) Photomicrograph of bladed crust of spar (arrows), which formed as a surface coating and grew into former pore space, displays an enterolithic morphology. Sections of this crust have been micritized. Latter generations of travertine have filled in around this crust. (E-H) Photomicrographs of the same area at low ( $\mathrm{E}$ and $\mathrm{G})$ and moderate $(F$ and $H)$ magnifications in plain light $(E$ and $F$ ) and fluorescence $(G$ and $H)$ microscopy. The most recent spar in this field of view is non-fluorescent (R) whereas older sparry areas with micrite envelopes are brightly fluorescent $(\mathrm{O})$. Bright fluorescence indicates an abundance of organic matter within the spar. ( $G$ and $H$ ) Higher magnification views of the central field of view shown in $(E$ and F). Observe that the outlines of the original spar crystals can still be recognized in the outer parts of the areas of the older spar which has been micritized $(M)$ and that even the still sparry sections of the older spar is brightly fluorescent.

(A) Microphotographie au microscope électronique à balayage de rhomboèdres cristallins de calcite fins à moyens comprenant de nombreux trous. Les trous étaient occupés par des pédoncules de diatomées, la matière végétale ayant été retirée par la cuisson
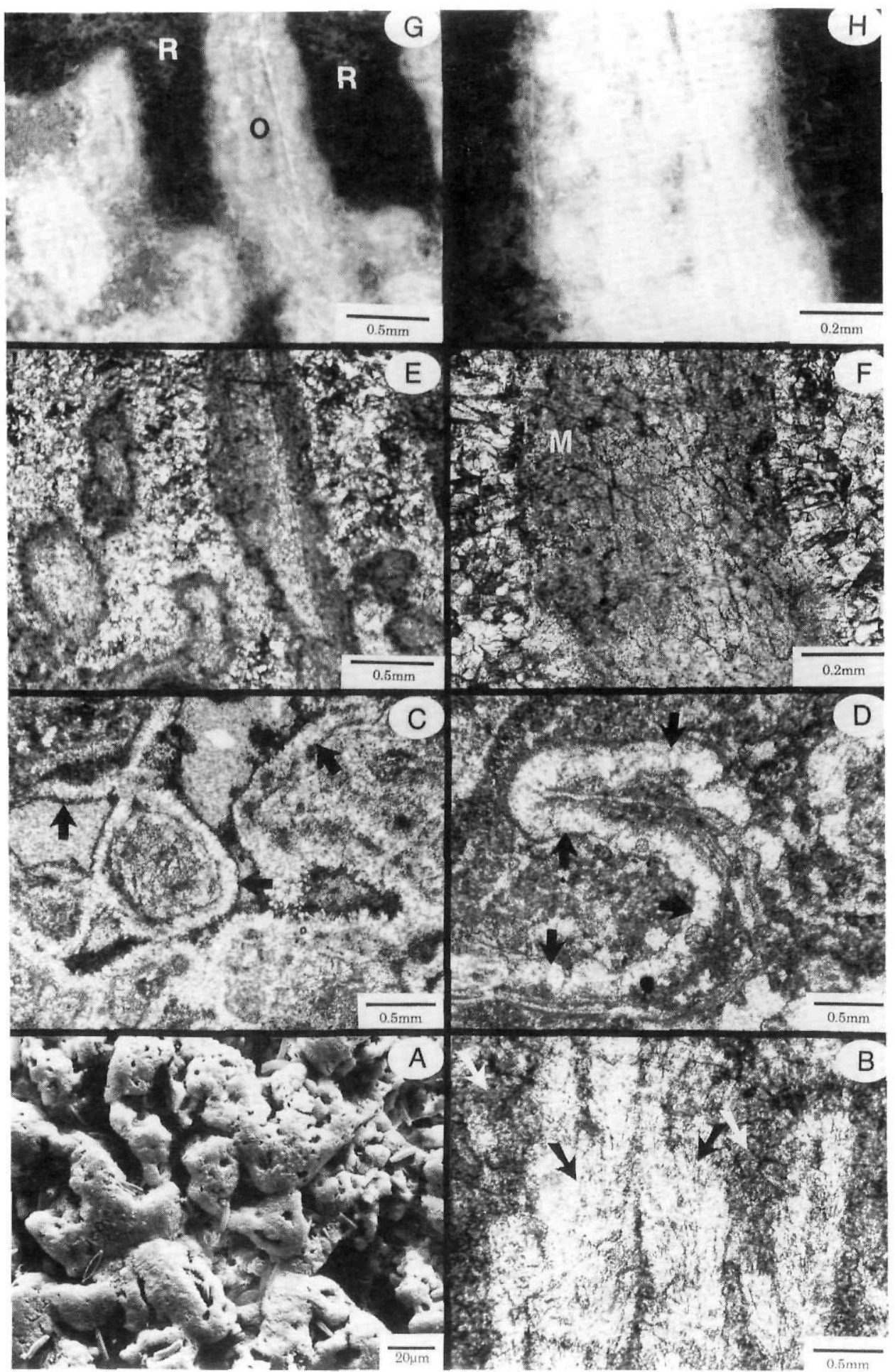

sous vide de l'échantillon.

(B) Microphotographie de cristaux

de sparite en lame avec des touffes de cyanophyte en forme d'éventail (flèches noires). Les zones de micrite (flèches blanches) sont d'anciens cristaux de sparite en lame micritisés. (C) Microphotographie montrant les rebords isopaques de sparite en lame (flèches) qui bordent des pores anciens et actuels. (D) Microphotographie d'une croûte en lame de sparite (flèches), d'abord un enduit, qui s'est accrue dans un ancien pore; elle est de forme entérolithique. Certaines sections de la croûte ont été micritisées. Des générations ultérieures de travertin se sont formées autour de la croûte. ( $E-H)$ Microphotographies de la même zone à faible ( $E$ et $G$ ) et moyen ( $F$ et $H$ ) agrandissement en microscopie à la lumière ordinaire ( $E$ et $F$ ) ou fluorescente ( $G$ et $H)$. La sparite la plus récente dans cette partie est non fluorescente (R), alors que les zones d'anciennes sparites avec enveloppes de micrite sont très fluorescents $(O)$. Une forte fluorescence montre qu'il y a abondance de matière organique à l'intérieur de la sparite. ( $G$ et $H$ ) Plus fort agrandissement de la partie centrale de (E et F). Observer que la configuration des cristaux de la sparite d'origine peut encore être perçue dans les parties externes de l'ancienne sparite micritisée (M) et que les sections demeurées sparitiques de la sparite plus ancienne sont très fluorescentes. 


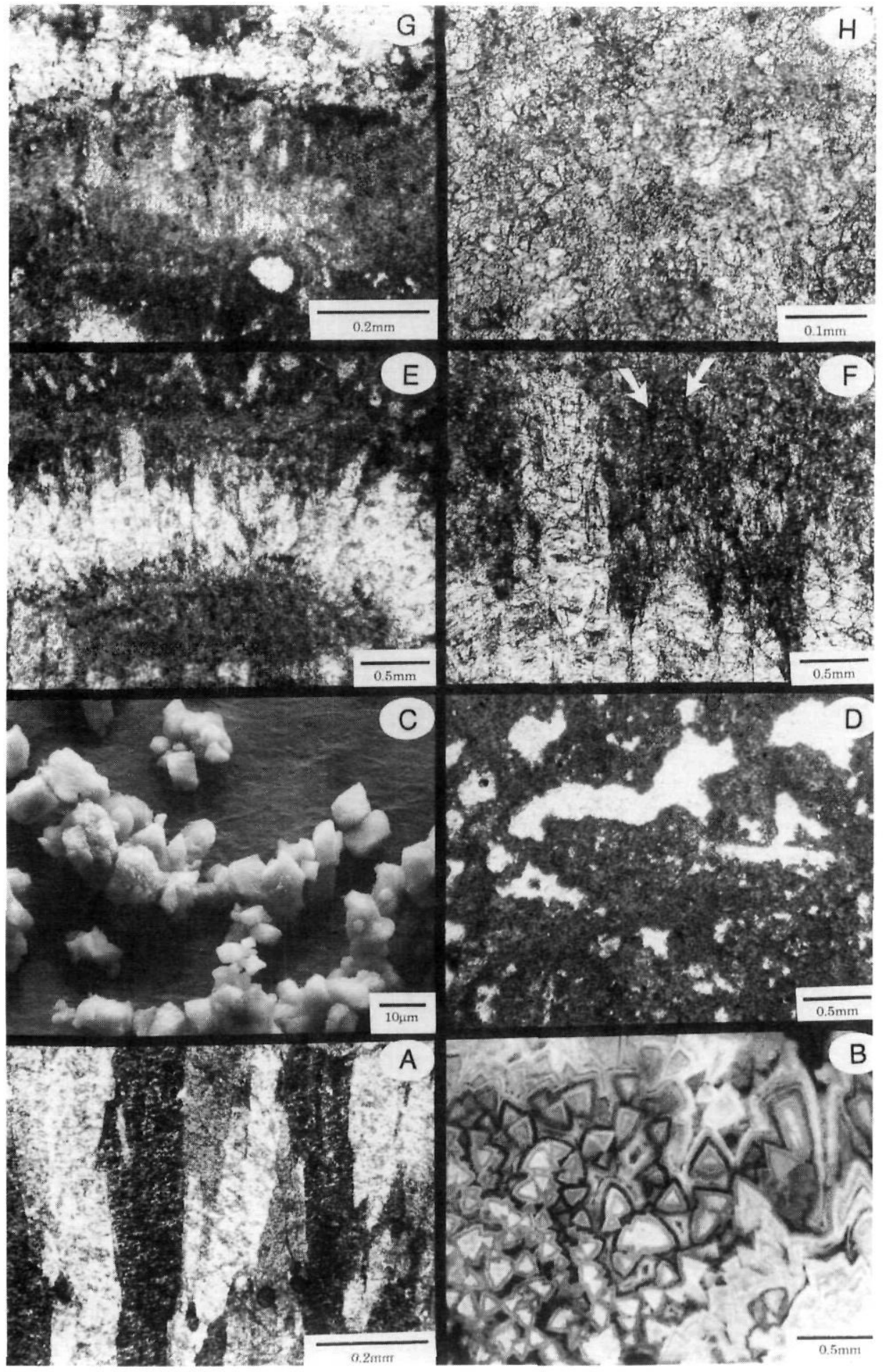

FIGURE 3. (A) Crossed polars photomicrograph of extremely coarse columnar crystals of spar which are typical of those which comprise flowstone crusts, both within these deposits and speleothem-like deposits from locations worldwide. (B) Fluorescent photomicrograph of spar prisms with triangular cross sections. Observe the convex outward curvature to the trigonal crystal faces. (C) Scanning electron micrograph of sample from old lake bed. Most of the calcite is composed of aphanocrystalline to very finely crystalline moderately to well-developed rhombohedrons. These rhombohedrons appear, in general, to be better developed than those presently forming within the modern lakes. (D) Photomicrograph of thoroughly micritized travertine, the light areas are pore spaces. (E, F, and G) Photomicrographs of bladed crystals of spar, which have undergone moderate ( $\mathrm{E}$ and $F)$ to thorough $(G)$ sparmicritization. (E) Crust of bladed spar which has been partially micritized. (F) Higher magnification view of the center of the field of view shown in (E). The top part of the bladed crystals in the center have been micritized, the original outline of these crystals is still evident (arrows). (G) Within the same sample, a similar crust, horizontally oriented in the photomicrograph, has been almost completely micritized. $(\mathrm{H})$ An area that was originally composed of equidimensional finely crystalline spar is now dominantly composed of micrite. The spar origin is indicated by the relict rhombohedral crystal outlines still evident even within the thoroughly micritized material.

(A) Microphotographies à polariseurs croisés de cristaux collonaires de sparite très grossière qui sont représentatifs de ceux qui comprennent des croûtes de dripstone, dans ces dépôts ou du type des dépôts de caverne à travers le monde. (B) Microphotographie à lumière fluorescente de prismes de sparite à coupe triangulaire. Observer la convexité des faces trigones des cristaux. (C) Microphotographie au micoscope électronique à balayage d'un échantillon de l'ancien fond de lac. La plus grande partie de la calcite est composée de rhomboèdres plus ou moins bien élaborés d'apparence aphanitique à très finement cristallisée. Ces rhomboèdres semblent généralement mieux élaborés que ceux qui sont en voie de formation dans les lacs actuels. (D) Microphotographie de travertin fortement micritisé; les parties plus claires sont des pores. (E, F et G) Microphotographies de cristaux de sparite en lame qui ont été moyennement (E et $F$ ) à fortement micritisés (G). (E) Croûte de sparite en lame partiellement micritisée. (F) Agrandissement de la partie centrale de la section montrée en (E). La partie supérieure des cristaux en lame du centre a été micritisée, la configuration originelle de ces cristaux étant encore visible (flèches). (G) Du même échantillon, une croûte semblable orientée horizontalement, presque entièrement micritisée. (H) Zone originellement presque entièrement composée de sparites de cristaux fins équidimensionnels, maintenant presque entièrement micritisée. Le spath originel est indiqué par la présence encore visible des contours rhomboédriques reliques. 
FIGURE 4. (A) Pain light ( $A$ and $D)$, fluorescent ( $B$ and $C)$, and white card (E and $F$ ) photomicrographs; $(A$ and $B)$ are of the same area as are (D and $E)$. ( $A$ and $B$ ) This sample is composed of subequal amounts of spar and micrite. Both the sparry and micritic areas have been bored by microbial organisms, this is evident when viewed using fluorescent microscopy, e.g., both areas fluoresce brightly. Comparison of plain light (A) and fluorescent (B) photomicrographs shows that the micritic areas have a higher density of borings. Higher magnification of the central area of (A and B) shows that most of the borings are straight, although curved traces of borings are also in abundance $(C)$. (D and $E$ ) This sample, different than (A-C), is also composed of subequal amounts of micrite and spar. The very inexpensive and readily set-up white card technique (Folk, 1987) also makes readily apparent the abundance of microbial borings. Higher magnification of the lower righthand portion of $(E)$ is shown in $(F)$, as in $(C)$ most of the borings are straight.

(A) Microphotographies prises à lumière ordinaire ( $A$ et $D)$, fluorescente $(B$ et $C$ ) et par la technique du carton blanc. ( $A$ et $B$ ) montrent la même zone, ainsi que ( $D$ et $E$ ). $(A$ et $B)$ Cet échantillon est composé de quantités presque égales de sparite et de micrite. Les zones de sparite et de micrite ont toutes deux été creusées par des organismes microbiens, ce qui ressort bien à la lumière fluorescente. $\mathrm{La}$ comparaison des microphotographies à lumière ordinaire $(A)$ et à lumière fluorescente $(B)$ montre que les zones micritisées sont plus densément creusées. L'agrandissement des parties centrales de (A et $B)$ montre que la plupart des trous sont rectilignes, bien que des traces de courbes soient également nombreuses $(C)$. (D et $E) C e t$ échantillon, différent de celui de (A à C), comprend aussi une quantité presque égale de micrite et de sparite. La technique du carton blanc (Folk, 1987), facile et peu coûteuse, fait également ressortir les nombreux trous microbiens. (F) L'agrandissement de la partie inférieure droite de (E) montre aussi que la plupart des trous sont rectilignes.

stages of micritization due to microbial action, from the essentially pristine non-fluorescent examples, i.e., containing no evidence of microbial boring, to pervasively micritized material whose spar origin can only be interpreted by comparison with laterally adjacent crystals (Fig. 3e-g). The recently formed pristine layers of spar are essentially the only carbonates within these deposits that do not fluoresce (Fig. $2 \mathrm{~g}-\mathrm{h}$ ). Whereas many of the spar layers do not appear to have been extensively micritized when viewed using standard petrographic techniques, they nevertheless display significant levels of fluorescence (Fig. 5b-c). The fluorescence indicates that the spar contains an abundance of organic material, which higher magnification observations show is due to borings by microbial organisms (Fig. 4). As older spar is micritized, new spar crusts precipitate on exterior surfaces as well as lining all interior pores. Consequently, individual samples display multiple generations of spar which have undergone various degrees of sparmicritization (Fig. 5a). This sparmicritization occurs throughout the waterfall and barrier deposits, a diagenetic process pervasive in these accumulations because of the luxuriant floral growth in the Plitvice Lakes environs. This process can result in a thoroughly micritized accumulation in which evidence of the original spar composition has been completely obliterated (Fig. 3d).

\section{CONCLUSIONS}

The waterfall and barrier travertines comprising the Plitvice Lakes travertine deposits essentially all originates as calcite spar. The initial deposits are composed of biologically 

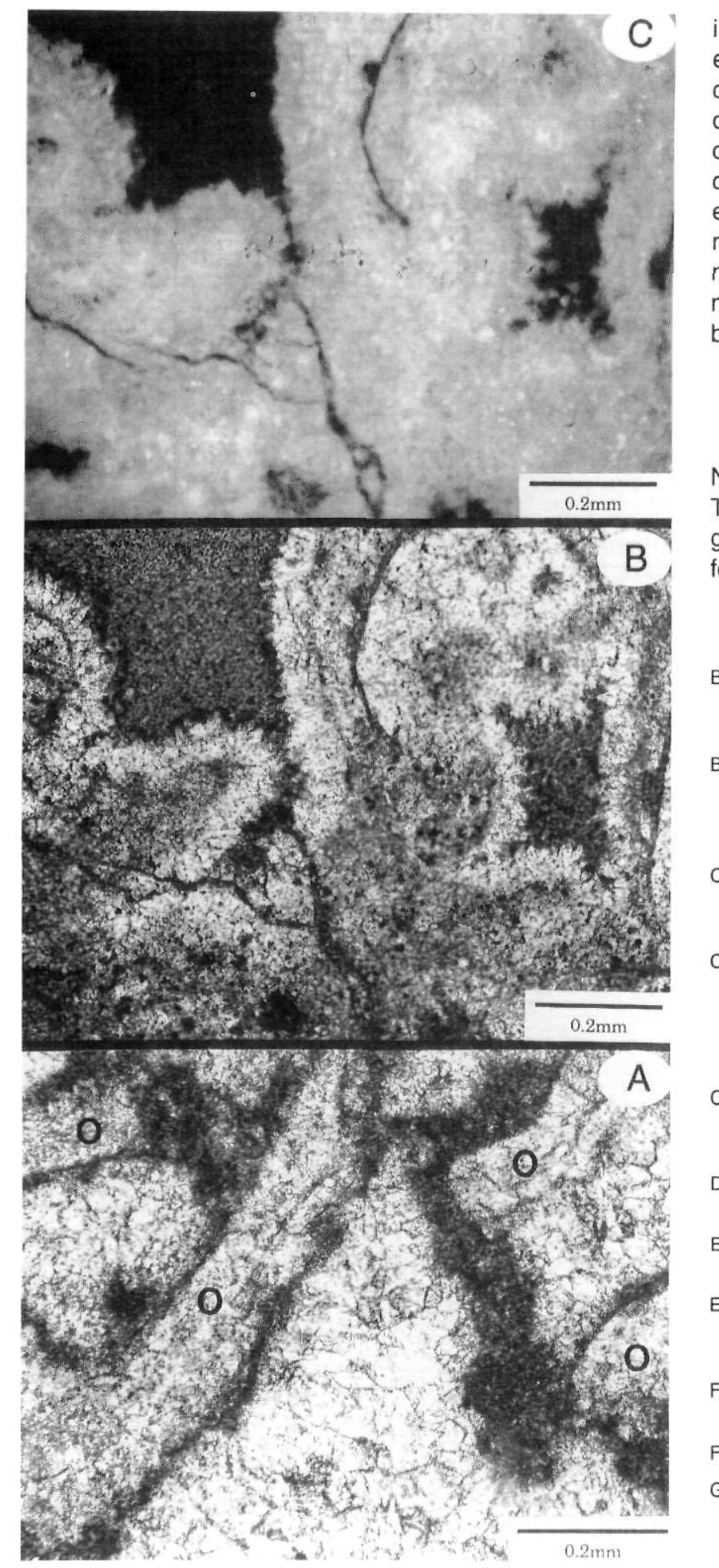

FIGURE 5. (A) Photomicrograph shows multiple generations of spar within the same sample. The older generation $(O)$ is surrounded by micrite envelopes and is a light $\tan$ in plain light. ( $\mathrm{B}$ and $\mathrm{C}$ ) Plain light (B) and fluorescent (C) photomicrographic pair. Observe that the clear isopachous spar rims of bladed calcite fluoresce only slightly less than the micritic areas, indicating that all of the calcite has organic material within it, i.e., microbial borings. The black areas are pore space. induced coatings of fine spar on plant surfaces. This is generally succeeded by abiotically precipitated crusts of clear, coarse bladed spar cement. And in the older travertine deposits, abiotically precipitated centimeter-thick, flowstone crusts composed of extremely coarse columnar spar forms as coatings over much of the travertine. Most of the earlier generations of spar are subsequently micritized due to borings by microbial organisms. As a consequence of sparmicritization, most of the older deposits of travertine are composed of micrite and their original composition can only be recognized by careful petrographic analyses.

\section{ACKNOWLEDGEMENTS}

We gratefully acknowledge the financial support by N.S.F., i.e., U.S.-Yugoslav Joint Board for Scientific and Technological Cooperation, Project JF 800. We are also grateful to Dr. André Desrochers and an anonymous reviewer for their useful suggestions.

\section{REFERENCES}

Braithwaite, C.J.R., 1979. Crystal textures of recent fluvial pisolites and laminated crystalline crusts in Dyfed, South Wales. Journal of Sedimentary Petrology, 49: 181-194.

Brnek-Kostic, A., 1989. Plitvice Lakes: A product of the eternal life cycles of organic and inorganic matter, p. 15-27. In J. Movcan and P. Niksic, eds., Plitvice Lakes National Park: The World National Heritage (2nd. ed.). Turistkomerc, Zagreb, $51 \mathrm{p}$.

Chafetz, H.S. and Folk, R.L., 1984. Travertines: Depositional morphology and the bacterially constructed constituents. Journal of Sedimentary Petrology, 54: 289-316.

Chafetz, H.S., Wilkinson, B.H. and Love, K.M., 1985. Morphology and composition of non-marine carbonate cements in near-surface settings, p. 337-347. In N. Schneidermann and P.M. Harris, eds., Carbonate Cements. Society Economic Paleontologists and Mineralogists, Special Publication 36, $379 p$

Chafetz, H.S., Rush, P.F, and Utech, N.M., 1991. Microenvironmental controls on mineralogy and habit of $\mathrm{CaCO}_{3}$ precipitates: An example from an active travertine system. Sedimentology, 38: 107-126.

Dravis, J.J. and Yurewicz, D.A., 1985. Enhanced carbonate petrography using fluorescence microscopy. Journal of Sedimentary Petrology, 55: 795-804.

Emig, W.H., 1917. Travertine deposits of Oklahoma. Oklahoma Geological Survey Bulletin, 29: 9-76.

Emeis, K.-C., Richnow, H.-H. and Kempe, S., 1987. Travertine formation in Plitvice National Park, Yugoslavia: Chemical versus biological control. Sedimentology, 34: 595-609.

Folk, R.L., 1987. Detection of organic matter in thin-section of carbonate rocks using a white card. Sedimentary Geology, 54: 193-200.

Ford, T.D., 1989. Tufa - the whole dam story. Cave Science, 16: 39-49.

Golubic, S., 1969. Cyclic and noncyclic mechanisms in the formation of travertine. International Association Theoretical and Applied Limnology, Proceeding, 17: 956-961.

(A) Microphotographie montrant les multiples générations de sparites à l'intérieur du même échantillon. La plus ancienne génération (O), de couleur havane pâle à la lumière ordinaire, est entourée d'enveloppes micritiques. Microphotographies à lumière normale $(B)$ et fluorescente $(C)$ de la même zone. Observer que les bordures isopaques de sparite de calcite en lame sont légèrement moins sensibles à la fluorescence que les zones micritisées, ce qui montre que toute la calcite contient du matériel organique. Les zones noires représentent des pores. 
1973. The relationship between blue-green algae and carbonate deposits, p. 434-472. In N.G. Carr and B.A. Whitton, eds., The Biology of Blue-Green Algae, Blackwell, Oxford, $676 \mathrm{p}$.

Huntsman, S. A. and Sunda, W. G., 1980. The role of trace metals in regulating phytoplankton growth: with emphasis on $\mathrm{Fe}, \mathrm{Mn}$ and $\mathrm{Cu}, \mathrm{p} .285-328$. In $\mathrm{E}$ I. Morris, ed., The Physiological Ecology of Phytoplankton. University California Press, Berkeley, $625 \mathrm{p}$.

Jones, B. and McDonald, R.W., 1989. Micro-organisms and crystal fabrics in cave pisoliths from Grand Cayman, British West Indies. Journal of Sedimentary Petrology, 59: 387-396.

Julia, R., 1983. Travertine, p. 64-72. In P.A. Scholle, D.G. Bebout, and C.H. Moore, eds., Carbonate Depositional Environments. American Association Petroleum Geologists, Tulsa, Memoir 33, 708 p

Kahle, C.F., 1977. Origin of subaerial Holocene calcareous crusts: Role of algae, fungi and sparmicritization. Sedimentology, 24: 413-435.

Kempe, S. and Emeis, K., 1985. Carbonate chemistry and the formation of Plitvice Lakes, p. 351-383. In E.T. Degens, S. Kempe, and R. Herrera, eds. Transport of Carbon Minerals in Major World Rivers, Pt. 3. Mitt. Geologisch-Palaontologisches Institut Universitat Hamburg (SCOPE/ UNEP Sonderband), 58

Kendall, A.C. and Broughton, P.L., 1978. Origin of fabrics in speleothems composed of columnar calcite crystals. Journal of Sedimentary Petrology, 48 519-538.

Love, K.M., 1985. Petrology of Quaternary travertine deposits, Arbuckle Mountains, Oklahoma. M.Sc. Thesis, University of Houston, 240 p.

Love, K.M. and Chafetz, H.S., 1988. Diagenesis of laminated travertine crusts, Arbuckle Mountains, Oklahoma. Journal of Sedimentary Petrology, 58: 441-445.

1990. Petrology of Quaternary travertine deposits, Arbuckle Mountains, Oklahoma, p. 65-78. In D.A. Hubbard, Jr. and J. Herman, eds., Travertine and Marl Deposits, Virginia. Virginia Department of Mines, Minerals, and Energy, $184 \mathrm{p}$.

Marker, M.E., 1971. Waterfall tufas: A facet of karst geomorphology in South Africa. Zeitschrift für Geomorphologie, Supp., 12: 138-152.

1973. Tufa formation in the Transvaal, South Africa. Zeitschrift für Geomorphologie, New Series, 17: 460-473.

Ordonez, S. and Garcia Del Cura, M.A., 1983. Recent and Tertiary fluvial carbonates in Central Spain, p. 485-497. In J.D. Collinson and J. Lewin, eds. Modern and Ancient Fluvial Systems. International Association Sedimentologists, Special Publication 6, $575 \mathrm{p}$.

Pedley, H.M., 1987. The Flandrian (Quaternary) Caerwys Tufa, North Wales: An ancient barrage tufa deposit. Proceedings Yorkshire Geological Society, 46: 141-152

Pentecost, A., 1978. Blue-green algae and freshwater carbonate deposits. Proceedings Royal Society London, B200, 43-61.

Pentecost, A. and Riding, R., 1986. Calcification in cyanobacteria, p. 73-90. In R. Riding and B.S.C. Leadbeater, eds., Biomineralization in Lower Plants and Animals. Systematics Association, 30, Clarendon, Oxford, $401 \mathrm{p}$.

Srdoc, D., Horvatincic, N., Obelic, B., Krajcar, I. and Sliepcevic, A., 1985. Procesl talozenja kalcita u krskim vodama s posebnim osvrtom na Plitvicka jezera, Krs Jugosl (Calcite deposition processes in karstwaters with special emphasis on Plitvice Lakes, Yugoslavia). Zagreb, Carsus Iugoslavie 11(4-6): 1-104 (English Summary, 98-104)

Stoffers, P., 1975. Recent carbonate sedimentation in the lakes of Plitvice (Yug.). Neues Jahrbuck für Mineralogie, 9: 412-418.

Weijermars, R., Mulder-Blanken, C.W. and Wiegers, J., 1986. Growth rate observation from the moss-built Checa travertine terrace, central Spain. Geological Magazine, 123: 279-286.

Winsborough, B.M. and Golubic, S., 1987. The role of diatoms in stromatolite growth: Two examples from modern freshwater settings. Journal of Phycology, 23: 195-201. 